\title{
Environmental Themes in Gendhing-Gendhing Ki Nartosabdho and Its Dissemination
}

\author{
Dhanang Respati Puguh*, Rabith Jihan Amaruli, and Mahendra Pudji Utama \\ Department of History, Faculty of Humanities, Universitas Diponegoro, Semarang, Indonesia
}

\begin{abstract}
Ki Nartosabdho (hereinafter Nartosabdho, 1925-1985), besides being known as a prominent dhalang, was also known as a very productive Javanese musical-masters. Hundreds of Javanese gendhing have been produced from the creative process. His works are very influential in the world of Javanese musical art until the present. Thematically his works are very numerous and diverse, some of which are about the environment. This article discusses Nartosabdho's environmental themes by using the literature study and document research methods. He works under the theme of the environment ranging from the beauty of nature, the beauty of nature as a tourist attraction, the destruction of nature, to preservation of the natural environment. The works were distributed to the public through performances, tapes, and books.
\end{abstract}

Keywords: Nartosabdho; Javanese karawitan; gendhing; environment.

\section{Introduction}

The environment has been a very important and strategic issue in Indonesia since the early 1980s. This is indicated by the enactment of Law Number 41982 regarding Basic Provisions for Environmental Management, Outlines of the State Policy 1983 which contains aspects of the environment, and the establishment of the State Ministry of Environment and Population which has the main task of managing the environment. The seriousness of the Government of the Republic of Indonesia in managing the environment is also shown by the existence of an Environmental Impact Assessment (EIA) policy that must be carried out on development projects that are considered to have an impact on environmental sustainability.

However, before the environment became an important and strategic issue in Indonesia's development program, several Javanese artists have paid attention to this issue. Ki Cokrowasito has perpetuated this environmental problem into a popular gendhing (Javanese repertoire) work of his day, entitled Penghijauan. Through gendhing, he warned against environmental damage due to deforestation in the mountains. Such vigilance needs to be increased given the dangers it poses, such as erosion which can result in the danger of flooding in areas around deforestation. Therefore, re-planting on the deforested forest is necessary to be done. By dense forest, there will be enormous benefits for the prosperity of the country.

* Corresponding author: dhanang.respati@live.undip.ac.id 
In addition to Cokrowasito, there are prominent Javanese artists who also pay attention to the environmental issue through his works, namely Nartosabdho. He is a productive Javanese musical master in producing gendhing. Because of his character in the Javanese musical world, Nartosabdho's work has been the object of study by several scholars including Becker [1], Sutton [2], Marsudi [3], Sukamso [4], Waridi [5], and Puguh [6]. Among the studies that have been done, there has not been any writing that specifically discusses environmental themes in the Nartosabdho's gendhing. This article aims to fill the gap, so that it can complement the previous studies. In order to provide a comprehensive discussion, the present article discusses three main relevant issues, namely the journey of Nartosabdho's artistic career, the environmental theme in Nartosabdho's gendhing, and its dissemination.

\section{Research Method}

This article was written by using the literature study method and document study. The literature is used in the form of articles, books and dissertations, while the document study is carried out by tracing tapes containing environmental themes by Nartosabdho produced by Lokananta record companies in Surakarta, Fajar Records in Semarang, and Kusuma Recording in Klaten. The information which is derived from various sources then selected and sorted based on relevant subject matter, and reconstructed into a complete story.

\section{Result and Discussion}

\subsection{Brief Biography of Ki Nartosabdho}

Previously, Nartosabdho was known as Sunarto born in Klaten on August 25, 1925. He was the son of the Parta Tanaya and Kencur couple who were also the youngest of seven siblings. His father was a mranggi (warangka keris maker) and also had skills in the musical field. When he was three years old, together with his brother (Mardanus), Sunarto had been invited by his father in the activities of klenengan or accompanying the dhalang of Klaten who were receiving stage requests. This routine continues until Sunarto began his formal elementary school education. His interests and talents in the arts are increasingly visible, growing, and developing. This is indicated by activities carried out outside school hours. In the afternoon he also learned to dance to R.M. Suraji and in the following years he also learned painting, playing guitar and violin, as well as learning to sing keroncong songs. Equipped with the abilities to play guitar, violin, and sing keroncong, then he joined the Sinar Purnama Orchestra. After unable to continue learning in formal education, he studied Javanese music more intensely. With his talent, at a very young age he has been able to play important instruments in Javanese gamelan, namely: fiddle, gender, and kendhang [7, 5].

Sunarto then devoted himself to the kethoprak groups and puppets of the wayang orang art which in the 1920-1930s were flourishing as a result of the development of urban society $[8,9]$. No less than 10 associations have been followed by performing in various cities. Through wandering with the kethoprak and wayang orang group, his knowledge and skills in Javanese music increased [7, 5].

In his wandering, he also performed tapa brata, an action that is often done by the Javanese if they want to achieve a certain position or glory in life. As stated by Nartosabdho to Ward Keeler and Bambang Sudinar (a member of Ngesti Pandowo), that he had been imprisoned at the age of 19 years and met with a legendary figure who had extraordinary powers, namely Sunan Kalijaga. According to him, this is what led him to have prominent artistic creations and innovations, so that gets a respectable place in the world of Javanese traditional performing arts [10]. 
In 1945 Sunarto joined Ngesti Pandowo, a wayang orang group led by Sastrosabdho. Ngesti Pandowo is a wayang orang group founded in Madiun, East Java on July 1, 1937. Since 1954, this community has been settled in Semarang and reached its heyday in the 19501970 and become the icon of Semarang [11]. In Ngesti Pandowo, he was accepted as a niyaga (gamelan player) specializing in playing the kendhang instrument. Sastrosabdho saw a strong impression that there was an outstanding talent and willingness in Sunarto. Sastrosabdho then gave him the opportunity to study his favorite art field, karawitan. At that time, the Indonesian Conservatory of Karawitan in Surakarta had just opened (1950) and Sunarto had the opportunity from Sastrosabdho to study with the Surakarta gamelan masters for two years. After two years studying musical art at the Indonesian Conservatory of Karawitan in Surakarta, he got the opportunity to become a musical leader in Ngesti Pandowo. Ngesti Pandowo's appearance underwent many changes, especially in the musical field. An innovative orchestra was created for Ngesti Pandowo, so that it becomes much more diverse and not monotonous $[12,7]$.

The remarkable progress which has been achieved finally got recognition and positive responses from Sastrosabdho. Because of his achievements, Sastrosabdho gave a gift to Sunarto. However, the prize is not in the form of material, but in the form of additional names "sabdho" behind his name. Since then, Sunarto changed his name to Nartosabdho. Ngesti Pandowo, under the leadership of Sastrosabdho and musical director Nartosabdho, is a truly innovative and sparkling kitsch theater [13]. The greatness of Ngesti Pandowo can be proven by the assumption that if someone visited Semarang, it would be incomplete if they have not watched the Ngesti Pandowo performance. Other evidence that supports that statement is the fact that President Sukarno always took time to watch the Ngesti Pandowo performance when he went to Semarang. Even so infatuated with the greatness of Ngesti Pandowo, President Sukarno often brought the Bambangan-Cakil of Ngesti Pandowo, which was performed by three artists of the association namely, Suwarni as Bambangan, Cipto as Cakil, and Nartosabdho as the host to entertain his guests [9].

Sastrosabdho always gives Nartosabdho the opportunity to develop himself and provide support to develop his talents and abilities as a dhalang. After becoming a dhalang (1958) and establishing the Paguyuban Karawitan Condhong Raos Raos (April 1, 1969), Nartosabdho progressively created and composed the repertoire of Javanese gendhing which, among others, were used to support his puppet show. Until the end of his life (1985), he has more or less created and composed 600 gendhing, which includes repertoire gendhing klenengan, gendhing beksan, gendhing pakeliran, gendhing pahargyan, and gendhing for film accompaniment [6]. According to Waridi, with his creative works and compositions, he has enriched the repertoire of Javanese gendhing. With his work, Nartosabdho is considered to be productive composer who becomes a pillar of life support for Surakarta Javanese music style [5].

Based on the contents of the lyrics, the gendhing of Nartosabdho have a variety of themes. Puguh has identified Nartosabdho's lelagon dhangdhut themes, namely: romance (from sincerity to betrayal of love); women's beauty; the beauty of music, dance and cultural nobility; natural beauty and tourism; friendship, family and humanity; social etiquette; traffic and others [6]. The environment is one of many themes from Nartosabdho's work.

\subsection{Environmental Themes in Gendhing-Gendhing Ki Nartosabdho}

Based on the book Kumpulan Gendhing Jawa Karya Ki Narto Sabdho (Collection of Javanese Gendhing by Ki Nartosabdho), and recordings of commercial tapes, it can be known gendhing with environmental themes. Based on his creative process, it can be ascertained that the lyrics were created based on Nartosabdho's empirical experience when he travelled to various regions in Indonesia, especially Java as long as he went through his career both as 
a composer of Javanese gendhing and a shadow puppeteer. The themes can be grouped into several sub-themes as follows.

\subsubsection{Natural Beauty}

The beauty of nature is a sub-theme in Nartosabdho's environmental themes. This is clearly seen in the lyrics of Ketawang Subakastawa which illustrated the beauty of the scenery in the mountains with the ravines around it. When viewed from distance the mountain looks bluish, covered with greenish yellow plants. The beauty amazed anyone who saw it. The feeling of amazement is getting more and more beautiful for anyone who sees it.

His description of the mountains is very detailed because it was also provided with a description of the activities of farmers in the fields. In the fields there are equipment to chase away rice-eating birds such as the statue of an exorcist (memedi padi) which is pulled from distance or blown by the wind. He also described fertile plants because of the sufficiency of running water inundating rice fields. Farmers grow crops using irrigation channels to irrigate rice fields. In the channels there are various animals that live in the fields such as yuyu (crab), belud (eel), and green frogs. The animals were lured and captured. Wader and cethul fish are also found in these channels. Rice fields are also used to raise ducks and goats. Farmers herd cattle, some are on the edge of rice fields, and some are temporarily on the edge of the river [14].

The beauty of the lake also draws Nartosabdho's attention. In his gendhing composition entitled Sang Lelana, he told about the journey of the wanderer who seeks to find clean and clear water to treat his thirst. Finally, he found a lake on the surface of the water there is a red lotus flower. In the lake with clear water there are fish swimming. With a feeling of pleasure the wanderer to the beautiful lake [15].

The beauty of clouds is another object explained in the theme of the environment. In the composition of the gendhing entitled Rimong Mega, Nartosabdho describes the beauty of clouds into a unity with the beauty of the mountain. According to him, the beauty of the mountain is very thrilling. Above it, there is a cloud like lush leaves that expand and soothe the heart. In the mountains there are also springs of abundant clear water, gurgling sound. At the end of the lyrics Nartosabdho gives awareness that all natural beauty is a creation of Allah and giving an implicit message that as humans we must be grateful and maintain its sustainability.

\subsubsection{The Beauty of Nature as a Tourist Attraction}

As described in the lyrics of Ladrang Pariwisata, that Indonesia has beautiful natural wealth. In the mountains there is a lake below which there are springs that flow throughout the year including during the dry season. At the top of the mountain a lot of very beautiful scenery. From the top of the mountain seen rental houses or hotels that can be used for tourists to stay. Flower gardens add to the natural beauty of the mountains. The roads have also been arranged well. Plants thrive and agricultural activity also develops. All of that makes tourism flourish, because the tourists feel incomparably happy with Indonesia's natural beauty.

According to Nartosabdho, Indonesia's beautiful natural environment is an attraction for tourists. Therefore, Indonesian people sometimes need to take the time to take a tour by visiting the countryside to enjoy the natural beauty of Indonesia in the form of forests and mountains. The natural beauty of Indonesia is also attracting the attention of foreign tourists. The beauty of nature which is a gift of God must be grateful, preserved, and utilized [15]. 


\subsubsection{Natural Damage: Landslide Disaster}

In addition to natural beauty and natural beauty as a tourist attraction, Nartosabdho also paid attention to the issue of natural destruction. Through the Ladrang Jurang Jugrug, Nartosabdho reminded his listeners to be aware of the danger of landslides that often occur in mountainous areas due to deforestation, thus disrupting irrigation channels in agricultural areas. Therefore, all members of the community both in rural and mountainous areas must work together to overcome this problem. A very important step to take is to carry out tree planting activities. With fertile trees and good paddy farming, the plants will flourish which ultimately increase the prosperity of the community [15].

\subsubsection{Preservation of the Rural Natural Environment}

Preservation of the rural natural environment needs to be considered, through Nartosabdho's Ladrang Desaku. In this gendhing, he said that rural natural environment needs to be preserved because life in the countryside has begun to be abandoned. This is because the development of the city is very fast, more crowded, and attactive, so that it becomes an attraction for rural people to work in the city. Yet as is well known, that the village was the origin of many people, producers of foodstuffs whose crop production is beneficial for urban communities. Therefore, villages need to be preserved and cared for [15]. The preservation and maintenance of the rural natural environment can be done, among others, by carrying out clean village campaign which are an obligation for the community members [15].

\subsection{Dissemination on Gendhing with Environmental Themes of Ki Narto- sabdho}

The dissemination of environmental-themed gendhing works by Nartosabdho was carried out through various means and media, namely performances, cassette, and books. Dissemination through the performance channel is carried out both through the Ngesti Pandowo performance and the shadow puppet performance by Nartosabdho himself. In this case, it is usually presented at klenengan event before the performance begins or at the gara-gara scene.

Dissemination through cassette is carried out by record companies both public and private company. Along with the development of recording media technology, the recording of the gendhing is then transferred to the compact disc. The gendhing were part of the recording album of the gendhing presented by the Paguyuban Karawitan Condhong Raos led by Nartosabdho.

Lokananta, a public-owned record label in Surakarta, is a record company that has a role in the dissemination of environmental-themed gendhing works by Nartosabdho [16, 17]. This is because none other than during the period 1957 to 1985, Lokananta had recorded recordings of works by Nartosabdho. The music presented by Nartosabdho is very popular in two senses, which are very well known by the public and very commercially successful. The recording albums contain innovative features from various regions, but their roots are solidly grounded in the Surakarta tradition [18]. Based on the sources that can be found, there are two album tapes produced by Lokananta that contain environmental themes. Ketawang Subakastawa is contained in the album titled Gending2 Tjiptaan Ki Nartosabdo [19], and Ladrang Pariwisata and Ladrang Jurang Jugrug are contained in the album titled Sarung Jagung [20].

Besides Lokananta, there are two private recording companies that record environmentalthemed gendhings by Nartosabdho namely Fajar Record in Semarang and Kusuma Recording in Klaten. Ladrang Pariwisata is contained in the album titled Ketawang Ibu Pretiwi [21]; 
Lancaran Bersih Desa are found in the Ki Nartosabdho's memories album (Album Kenangan) (22); Sang Lelana is on the album titled Kutut Manggung [23], while Rimong Mega is on an album titled Wira-Wiri [24].

These commercial records are the media which have an important position and role for the dissemination of Nartosabdho's works. Through commercial recordings, Nartosabdho's gendhing are often broadcast to the Javanese public through public-owned radio stations (Radio Republik Indonesia, RRI) and private radios in both Central and East Java. RRI Jakarta Central Station, RRI Nusantara II Yogyakarta, RRI Surakarta, RRI Semarang, and RRI Surabaya are radio stations that frequently broadcast recordings of Nartosabdho's gendhing.

Books that contain notations and lyrics of gendhing by Nartosabdho are another media to disseminate Nartosabdho's works. The books that contain Nartosabdho's works are almost complete, a book titled Kumpulan Gendhing Jawa Karya Ki Narto Sabdho, consisting of four volumes, published by the Central Java Arts and Culture Development Project. The publication of this book was done with a documentative purpose, namely to save the works of Nartosabdho's gendhing. Therefore, it is undoubtedly contains gendhing-gendhing which concerns about the environmental issues. The books are distributed to government agencies, arts and culture practitioners in Central and East Java. With various kinds of media and channels, the gendhing of Nartosabdho is widely known by the public and partly engraved in the hearts of the people because it is a part of people's lives.

\section{Conclusion}

Based on the above description, the conclusion of this article is the following conclusions. Nartosabdho's environmental themes are created not in a vacuum, but are an artist's response to Indonesia's social, economic, political and cultural situation. The works were created as an effort by Nartosabdho to translate important ideas about the environment into a language that can be understood by supporters of Javanese culture and Javanese music lovers, especially connoisseurs of Nartosabdo's gendhings. Through performances, cassette tapes, and book publishing -gendhing were disseminated, so that they were known and popular in the community.

\section{References}

1. J.O. Becker. Traditional Music in Modern Java: Gamelan in a Changing Society. Honolulu: University of Hawaii Press (1980).

2. A.R. Sutton. Traditions of Gamelan Music in Java: Musical Pluralism and Regional Identity. Cambridge: Cambridge Univeristy Press (1991).

3. M. Marsudi. Ciri Khas Gendhing-gendhing Ki Nartosabdo: Suatu Kajian Musikologi dalam Karawitan. Master Thesis Postgraduate Program, Universitas Gadjah Mada, Yogyakarta (1998).

4. S. Sukamso. Peranan Gendhing-gendhing Ki Nartosabdo dalam Pelatihan Karawitan Anak Asriraras di Kampung Ngelosari, Desa Kalibata Kecamatan Mojogedang, Kabupaten Karanganyar”. Master Thesis Postgraduate Program, Universitas Gadjah Mada, Yogyakarta (2002).

5. W. Waridi. Gagasan \& Kekaryaan Tiga Empu Karawitan: Pilar Kehidupan Karawitan Jawa Gaya Surakarta 1950-1970an (Ki Martapengrawit, Ki Tjakrawasita, Ki

Nartasabda). Bandung: Etno Publisher-BACC-Pascasarjana ISI Surakarta, p. 339 (2008). 
6. D.R. Puguh, Tentang Lelagon Dhangdhut Karya Ki Nartosabdho, in E.S. Hardiati and Rr. Triwurjani (ed.). Pentas Ilmu di Ranah Budaya: Sembilan Windu Prof. Dr. Edi Sedyawati Denpasar Bali: Pustaka Larasan bekerja sama dengan Panitia 72 Tahun Prof. Dr. Edi Sedyawati, dan Tembi Rumah Budaya (2010).

7. S. Sumanto. Nartosabdo: Kehadirannya dalam Dunia Pedalangan (Sebuah Biografi). Surakarta: STSI Press, p. 17-20 (2002);

8. R. Rustopo. Menjadi Jawa: Orang-orang Tionghoa dan Kebudayaan Jawa di Surakarta 1895-1998. Yogyakarta: Ombak, p. 139-142 (2007).

9. D.R. Puguh, R. J. Amaruli, M.P. Utama. Teater Kitsch Ngesti Pandowo di Kota Semarang Tahun 1950-an-1970-an. Mozaik Humaniora, Vol. 17 No. 1 Januari-Juni, p. 5-6 (2017).

10. W. Keeler. Javanese Shadow Plays, Javanese Selves. New Jersey: Princeton University Press, p. 200 (1987).

11. D.R. Puguh, M.P. Utama, R.J. Amaruli. Peranan Perguruan Tinggi di Semarang dalam Pelestarian Wayang Orang Ngesti Pandowo. Jurnal Sejarah Citra Lekha, Volume 4, No. 2, p. 137-152, (2019).

12. D.R. Puguh. Perkumpulan Wayang Orang Ngesti Pandhowo: Perjalanan Pertumbuhan, Kejayaan, dan Kemundurannya. Paper for Discussion Apresiasi Pedalangan II, Faculty of Letters, Universitas Diponegoro (1990).

13. U. Kayam. Ngesti Pandowo: Suatu Persoalan Kitsch di Negara Berkembang, in Edi Sedyawati and Sapardi Djoko Damono. Seni dalam Masyarakat Indonesia: Sebuah Bunga Rampai. Jakarta: Gramedia, p.131 (1983).

14. "Pustaka Saniskara Ki Nartosabdho". Collection of Dhanang Respati Puguh.

15. A. Sugiarto, et al. Kumpulan Gendhing Jawa Karya Ki Narto Sabdo. Semarang: Proyek Pengembangan Kesenian dan Kebudayaan Jawa Tengah, p. 192 (1996/1997).

16. D.R. Puguh. Mengagungkan Kembali Seni Pertunjukan Tradisi Keraton: Politik Kebudayaan Jawa Surakarta, 1950an-1990an. Dissertation on Postgraduate Program, Faculty of Culture Sciences, Universitas Gadjah Mada, Yogyakarta (2015).

17. D.R. Puguh. Perusahaan Rekaman Lokananta, 1956-1990-an: Perkembangan Produksi dan Kiprahnya dalam Penyebarluasan Seni Pertunjukan Jawa Surakarta. Sasdaya: Gadjah Mada Journal of Humanities, Vol. 2 No. 2 Mei (2018).

18. P. Yampolsky. Lokananta: a Discography of The National Recording Company of Indonesia, 1957-1985. University of Wisconsin, Center for Southeast Asian Studies, p. 15 (1987).

19. Gending2 Tjiptaan Ki Nartosabdo. Surakarta: Lokananta, ACD 007.

20. Sarung Jagung. Surakarta: Lokananta, ACD 021.

21. Ketawang Ibu Pretiwi. Semarang: Fajar Record 9102.

22. Album Kenangan Ki Nartosabdho Vol. 1. Semarang: Fajar Record 776

23. Kutut Manggung. Semarang: Fajar Record 9151.

24. Wira-wiri. Klaten: Kusuma Recording KGD 068. 